\title{
REUSE OF THE AQUEOUS PHASE OF BIO-OIL FRACTIONATION AS A WATER-REPELLENT AGENT FOR WOOD
}

\author{
Caio Silvestre Lima Sanson ${ }^{1}$, Ivana Amorim Dias ${ }^{1}$; Marina Gorgete Santos ${ }^{1}$, Bruno de Miranda ${ }^{2}$, Pedro Henrique \\ Gonzalez de Cademartori ${ }^{1,3 *}$ \\ ${ }^{1}$ Programa de Pós-Graduação em Engenharia Florestal, Universidade Federal do Paraná, Campus Jardim Botânico, Curitiba, Paraná, Brasil, \\ caiosanson@ufpr.br; ivanaamorim1@ @otmail.com; marinagorgete@ufpr.br \\ ${ }^{2}$ Engenharia Industrial Madeireira, Universidade Federal do Paraná, Campus Jardim Botânico, Curitiba, Paraná, Brasil, \\ bruno.miranda@ufpr.br \\ ${ }^{3}$ Departamento de Engenharia e Tecnologia Florestal, Universidade Federal do Paraná, Campus Jardim Botânico, Curitiba, Paraná, Brasil, \\ pedroc@ufpr.br
}

Received for publication: 20/12/2019-Accepted for publication: 24/06/2020

\begin{abstract}
Resumo
Reaproveitamento do resíduo líquido do fracionamento de lignina pirolítica como agente protetor de madeira. A extração da lignina pirolítica do bio-óleo de biomassa pode ser feita por um método simples sob agitação em água ou solventes orgânicos, o qual resulta uma fração insolúvel em água (lignina pirolítica) e uma fração solúvel em água (WS). Este estudo fez uso da técnica de fracionamento físico com água como agente líquido para separar as duas frações do bio-óleo de pirólise rápida e obter a WS, principal elemento desta pesquisa como agente protetor de materiais lignocelulósicos. O objetivo do estudo foi investigar a eficiência da fase aquosa (WS) como agente hidrorrepelente quando incorporado à madeira de Pinus elliotti. Foram utilizadas duas proporções de água e bio-óleo (1:50 e 1:100) e duas velocidades de agitação (17.000 e 8.500 RPM) para obtenção da WS, chamando-as de $\mathrm{WS}_{50}$ e WS 100 , ambas com rendimento médio de $61 \%$ de WS. Cromatografia gasosa acoplada com espectrometria de massas (GC-MS), termogravimetria (TGA), ângulo de contato e microscopia eletrônica de varredura (MEV) foram utilizados para caracterização da WS e das lâminas impregnadas com WS. Observou-se ausência de alterações morfológicas na superfície, especialmente o nãorecobrimento das pontoações da madeira, enquanto o TGA mostrou alterações visíveis no grau de degradação térmica do material impregnado, estas relacionadas à composição química da WS identificada no GC-MS Observou-se aumento significativo, em média $62 \%$, do ângulo de contato aparente da madeira impregnada, aproximadamente $126^{\circ}$. A WS comprovou seu potencial como agente protetor ao transformar a superfície hidrofílica da madeira de Pinus elliotti em hidrofóbica, característica parcialmente mantida após 45 dias de exposição.
\end{abstract}

Palavras-chave: Extração via água; bio-óleo de pirólise rápida; Molhabilidade da superfície; Hidrofobicidade.

Abstract

A simple method to extract pyrolytic lignin from bio-oil is under agitation in water or organic solvent. This process produces a water-insoluble fraction (pyrolytic lignin) and a water-soluble fraction (WS). In this study, we used a physical fractionation technique with water as a liquid agent to separate the two fractions of the fast pyrolysis bio-oil and obtain the WS - the object of study - to test its efficiency as a protective agent for lignocellulosic materials. The study aimed to investigate the efficiency of the aqueous phase (WS) as a waterrepellent agent when impregnated into Pinus elliotti wood. To obtain WS, we used two bio-oil:water ratios (1:50 and 1:100) and two agitation speeds (17,000 and 8,500 RPM); they were respectively named $\mathrm{WS}_{50}$ and $\mathrm{WS}_{100}$, both with an average yield of $61 \%$ WS. Gas chromatography coupled with mass spectrometry (GCMS), thermogravimetry (TGA), contact angle, and scanning electron microscopy (SEM) were used to characterize the WS and the veneers impregnated with it. There were no morphological changes on their surface, especially regarding the non-coating of the wood pits; meanwhile, the TGA showed visible changes in the degree of thermal degradation of the impregnated material related to the chemical composition of the WS identified in the GC-MS. There was a significant increase, on average $62 \%$, in the apparent contact angle of the impregnated wood, approximately $126^{\circ}$. The WS has shown to be efficient as a protective agent by converting the hydrophilic surface of Pinus elliotti into a hydrophobic one, and this effect partially remained after 45 days of exposure.

Keywords: water extraction; fast pyrolysis bio-oil; surface wettability; hydrophobicity.

\section{INTRODUCTION}

The thermochemical conversion of biomass is a certified way of reusing by-products (VASKALIS et. al, 2019). In addition, thermochemical conversion processes can substantially contribute to self-sufficiency in thermoelectric energy and fossil fuel substitution by using $100 \%$ of the biomass. Pyrolysis stands out among the existing thermochemical conversion processes. This process produces charcoal, bio-oil, and gas in different proportions depending on temperature, residence time, and heating rate. Bio-oil - produced in greater proportion by fast pyrolysis from converting condensable gases into a liquid, with temperatures between 400 and $600{ }^{\circ} \mathrm{C}-$ is the liquid fraction derived from biomass pyrolysis. Bio-oil is rich in phenolic compounds and short-chain

FLORESTA, Curitiba, PR, v. 51, n. 3, p. 557-566, jul/set 2021.

Sanson, C. S. L. et.al.

ISSN eletrônico 1982-4688

DOI: $10.5380 /$ rf.v51 i3. 70912 
carbohydrates which result from the thermal degradation of macromolecular components present in the chemical structure of wood (BRIDGWATER, 2003).

All types of thermochemical conversion, be it slow pyrolysis (carbonization), fast pyrolysis or gasification, have their liquid fraction derived from the condensation of condensable gases. Conditions such as temperature, residence time, pressure, reactor type, and raw material result in different aqueous phase yields for each process. The chemical compositions of the liquid fraction of these processes are similar in qualitative terms since they are products derived from the pyrolysis of wood and/or other types of biomasses, but they differ in quantity. Consequently, the literature varies when referring to the name of the liquid fraction derived from the gas condensation process. The liquid fraction can be generally called pyroligneous liquid, bio-oil, pyroligneous extract, pyroligneous acid, pyroligneous liquor (CAMPOS, 2007). However, the liquid fraction of slow pyrolysis (carbonization), for example, is called pyroligneous liquor, pyroligneous liquid or pyroligneous extract in Canal et al. (2016), whereas the liquid fraction of fast pyrolysis is called bio-oil in Zhang and Wu (2019).

Bio-oil is a two-phase microemulsion with two indistinct phases of polar and nonpolar materials, respectively derived from thermal degradation of both holocellulose and lignin. The breakdown of these fractions occurs through physical and chemical processes; in the first case, through extraction in water under agitation (Zhang and $\mathrm{Wu}, 2019$ ), and in the second, using organic solvents (GARCIA-PEREZ et al., 2007). The hydrophobic product of this separation is pyrolytic lignin, which has high carbon content and shows potential for industrial applications (BASUR, 2010), such as an additive in adhesives for wood panels (JIANG et al. 2010). There are also studies on its use as raw material for the production of carbon fibers (QIN; KADLA, 2012) and of aromatic compounds via catalytic pyrolysis (ZHAO et al. 2010).

Due to the chemical constitution of bio-oil regarding its polar and nonpolar components of low molecular weight (BASUR, 2010), the soluble fraction (or aqueous phase) obtained after the fractionation to produce pyrolytic lignin shows a high potential for use since it is rich in polar compounds derived from carbohydrates present in wood (MOHAN et al., 2006). Among the sectors of the industry that could benefit from this is that of fine chemicals, due to the recovery of acetic acid (RASRENDRA et al., 2011), a chemical compound widely used as raw material to produce vinyl acetate monomer and terephthalic acid (MIRASOL, 2009). Similarly, the aqueous phase can be used for isolating other chemical compounds of interest, such as levoglucosan and sugars (VITASARI et al., 2011).

However, when compared to the number of studies about pyrolytic lignin and its uses, there are few that delimit the chemical composition of the residual aqueous phase of the fractionation process and investigate potential applications that may allow its use as a material with increased value-added. In light of this, unlike crude bio-oil, which has been tested as an antifungal and hydrophobic agent for lignocellulosic materials (LOURENÇON et al., 2016), the residual aqueous phase from the fractionation to obtain pyrolytic lignin still lacks studies regarding its efficiency as a protective agent for lignocellulosic materials. Nevertheless, this product shows potential, especially because it is water-soluble, a characteristic that does not exist in crude bio-oil.

Biorefinery and sustainability in the production chain propel the search for interaction among wood products of renewable origin to improve the properties of the materials, especially products derived from waste from the forest and wood industries - such as fast pyrolysis bio-oil. The use of materials such as pyrolytic lignin or the aqueous phase to obtain materials with increased value-added aligns with these concepts. Therefore, the objective of this study was to investigate the potential of the aqueous phase derived from the fractionation of fast pyrolysis bio-oil as a water-repellent agent for the protection of the wood surface. Pinus elliotti wood was used as a substrate; the aim was to increase its resistance and impermeability when susceptible to surface contact with polar liquids (e.g. water), as occurs in civil construction, for example.

\section{MATERIALS AND METHODS}

\section{Material preparation}

The bio-oil produced from the tailings of Eucalyptus spp. chips in a fast pyrolysis pilot plant was used as a substrate to obtain the aqueous phase as an impregnating agent. The bio-oil was produced in a fast pyrolysis reactor at $500{ }^{\circ} \mathrm{C}$, with a reduced oxygen atmosphere, and static pressure of $100 \mathrm{~mm} \mathrm{H}_{2} \mathrm{O}$. The bio-oil used in this study had a density of $1.15 \mathrm{~g} . \mathrm{cm}^{-3}, \mathrm{pH} 3.3 \pm 0.1$, and a flash point of $-24 \pm 0.7^{\circ} \mathrm{C}$ (LOURENÇON et al., 2016).

We performed preliminary tests in wood samples of Pinus elliotti measuring 70 x 10 x $0.9 \mathrm{~mm}$ (length $\mathrm{x}$ width $\mathrm{x}$ thickness) in order to avoid contact of the droplets during the wettability test. The samples were kept in a climatic chamber at $20{ }^{\circ} \mathrm{C}$ of temperature and $65 \%$ of relative air humidity until the tests were performed.

\section{Bio-Oil fractionation}

As obtaining the aqueous phase is a relatively little tested procedure, the procedures that obtained the best results in the literature (ZHANG; WU, 2019) were carefully selected with the aim of increasing their yield and improving the process. The fractionation of the bio-oil occurred through a simple process of physical separation 
under vigorous dispersion in an Ultra-Turrax ${ }^{\circledR}$ T25 Digital (IKA) device. The fractionation conditions were established from previous laboratory experiments with the aim of improving the separation method. The scientific basis for the definition of the intervals of rotation speed and the ratio of bio-oil:water came from the procedures adopted and cited by Zhang and $\mathrm{Wu}$ (2019) because the authors sought a higher yield in the fractionation to obtain the aqueous phase. Preliminary tests showed that the high viscosity of the bio-oil used in this study prevented the adoption of lower rotational speeds and bio-oil:water ratios below 1:50 and, consequently, the achievement of satisfactory yields during fractionation. Thus, we performed the fractionation of bio-oil to obtain the aqueous phase (WS) at a speed of 17,000 rpm, in an attempt to improve phase separation (higher yield), and two bio-oil:water ratios (1:50 and 1:100). The treatments were named $\mathrm{WS}_{50}$ for the 1:50 ratio and $\mathrm{WS}_{100}$ for the 1:100 ratio.

In a container with cold distilled water $\left(1-5^{\circ} \mathrm{C}\right)$ and in an inverted water bath $\left(1-5^{\circ} \mathrm{C}\right)$, under ultravigorous agitation, the bio-oil was added drop by drop using a disposable syringe for 10 minutes. After 10 minutes, the mixture remained under ultra-vigorous agitation for another 15 minutes. The material obtained after the fractionation presented two phases, one composed of water-soluble materials, also called aqueous phase (WS), and the other composed of water-insoluble materials (WI), called pyrolytic lignin, which was found precipitated in the liquid.

We separated the phases and isolated the WS, the object of our study, through vacuum filtration in a Büchner funnel. The WI was retained in the filter paper while the WS was filtered. The material retained in the filter paper was kiln-dried at $90{ }^{\circ} \mathrm{C}$ to calculate the yield of the fractionation process, according to Equation 1 (adapted) described by Zhang et al. (2019). We determined the WS's pH on a pH meter, while we measured the solids content based on the methodology described by the ASTM D 1417 standard.

$$
R_{W S}=\frac{Z i}{M p o} \times 100 \% \quad \text { Equation } 1
$$

where: $R_{W S}=$ mass percentage $($ yield $)$ of the aqueous phase; $\left(Z_{i}\right)=$ filter mass containing solid material after drying; $\left(\mathrm{M}_{\mathrm{po}}\right)=$ mass of the amount of bio-oil used in the fractionation.

\section{Chemical composition of the aqueous phase by GC-MS}

Through gas chromatography (GC) coupled with mass spectrometry (MS), we were able to identify the main components of the aqueous phase. We performed the chromatographic analyses on a Shimadzu® gas chromatograph (model GCMS2010 Plus) coupled to a Tandem mass spectrometer (model TQ8040) with an autosampler (model AC 5000) and Helium (analytical 5.0) as a carrier gas. We analyzed the samples with the chromatographic column DB-5MS - 30m x $0.25 \mathrm{~mm} \times 0.25 \mu \mathrm{m}$ at a flow rate of $1.0 \mathrm{ml} \mathrm{min} \mathrm{m}^{-1}$. The injector and the ion source temperatures were maintained at $250{ }^{\circ} \mathrm{C}$ while the temperature of the interface was $300{ }^{\circ} \mathrm{C}$. We sustained the GC oven's initial temperature, $50{ }^{\circ} \mathrm{C}$ for 4 minutes, and subsequently increased in $10{ }^{\circ} \mathrm{C} \mathrm{min}{ }^{-1}$ until we hit $280^{\circ} \mathrm{C}$, and we sustained that temperature for 3 minutes, achieving a chromatographic run time of 30 minutes.

To determine the mass/load ratio (m/z) range of 60 to 400 in full scan mode, we used the GCMS Solution ${ }^{\circledR}$ software. The injected sample volume was $1 \mu 1$ and the split injection mode was applied in the ratio of 1:10. We transferred $200 \mu \mathrm{l}$ of the aqueous phase to chromatographic vial inserts and left them in a sample concentrator under vacuum at $40^{\circ} \mathrm{C}$ for 90 minutes to fully dry.

Each sample was reconstituted in $200 \mu \mathrm{l}$ of HPLC grade acetone and shaken in the vortex. To avoid solids injection into the chromatographic system, we only collected $150 \mu \mathrm{l}$ of the sample, which was transferred to another vial with an insert. The most intense peak compounds were refined in the same software for subsequent correlation of the results obtained.

\section{Impregnation of wood with the aqueous phase (WS)}

We impregnated fifty-six samples of Pinus elliotti wood veneers with the aqueous fractions $\mathrm{WS}_{50}$ and $\mathrm{WS}_{100}$. Prior to impregnation, the samples were kiln-dried at $100^{\circ} \mathrm{C}$ for 24 hours until a constant mass was obtained. For every 9 wood samples, $15 \mathrm{ml}$ of WS were added to a petri dish. We inserted the material into a desiccator connected to a vacuum pump, in which the vacuum impregnation process was performed. The wood veneers were impregnated under internal pressure of $650 \mathrm{mmHg}$ for 40 minutes. Subsequently, the treated samples were kiln-dried at $100^{\circ} \mathrm{C}$ for 24 hours to determine the WS load retained in the structure, i.e., the weight gain percentage of the wood after WS impregnation (WPG).

\section{Scanning electron microscopy (SEM)}

We investigated changes in the morphology of untreated wood and wood treated with WS in a TESCAN VEGA3 LMU scanning electron microscope. We previously coated the material with a thin layer of gold in a metallization device (via sputtering). We obtained high-resolution images at 400, 3,000, and 7,000 $\mathrm{x}$ magnifications. 


\section{Thermogravimetric analysis (TGA)}

We ground the samples of untreated wood and wood treated with WS in a Willey-type knife mill to obtain a material with low grain size. Subsequently, the WS-treated samples were kiln-dried at $100^{\circ} \mathrm{C}$ to obtain a powder. We subjected 6 to $8 \mathrm{mg}$ of the aqueous powder phase and of the ground wood for each treatment to thermogravimetric analysis in an SDT Q600 (TA Instruments) device. The analysis conditions were set to an inert atmosphere of nitrogen $\left(\mathrm{N}_{2}\right)$, heating rate of $10{ }^{\circ} \mathrm{C} / \mathrm{min}$, and exposure temperature range between 30 and $600{ }^{\circ} \mathrm{C}$.

\section{Surface wettability}

The degree of wettability of the surface of the untreated and the WS-treated wood veneers was investigated through the contact angle technique on a Krüss DSA25 goniometer (KrüssGmbH, Germany) through the sessile drop method. For each treatment, five samples were randomly selected for the trial. We distilled water droplets (surface tension $72.8 .10^{-3} \mathrm{~N} / \mathrm{m}$ ) with a volume of $5 \mu \mathrm{l}$ on the surface of the veneers. To investigate the kinetics of water droplet behavior, we determined the apparent contact angle (WCA) in 5, 15, 30, 45, and $60 \mathrm{~s}$. The data was subjected to a one-way ANOVA to verify the influence of the WCA treatments. In case of rejection of the null hypothesis, we performed Tukey range test at $95 \%$ confidence level.

We kept the material in a climatic chamber $\left(20^{\circ} \mathrm{C}\right.$ of temperature and $65 \%$ of relative humidity) for 45 days in order to investigate the behavior of impregnated wood regarding changes in wettability due to natural aging. The WCA was determined in a goniometer, considering the same conditions mentioned above, after 30 and 45 days of exposure (natural aging).

Distilled water was the only liquid capable of forming droplets on the surface of the material for WCA measurement purposes. Other polar and nonpolar solvents, such as acetone, ethyl acetate, and hexane, were tested, but they did not form droplets on the wood's surface that would allow the determination of the WCA.

\section{RESULTS}

\section{Chemical composition by GC-MS}

Table 1 shows the chemical compounds identified in the aqueous phase by GC-MS.

Table 1. Aqueous phase chemical compounds detected by GC-MS.

Tabela 1. Compostos químicos da fase aquosa detectados por GC-MS.

\begin{tabular}{cccc}
\hline Compound detected & rt (min) & Area \% & Family* \\
\hline (S)-(+)-2',3'-Dideoxyribonolactone & 12.026 & 1.14 & Furans \\
Catechol & 12.112 & 3.45 & Pyrocatechol and derivatives \\
1,4: 3,6-Dianhydro- $\alpha$-d-glucopyranose & 12.506 & 1.46 & Carbohydrate derivatives \\
2,3-dihydro-Benzofuran & 12.539 & 1.54 & Aromatic compounds \\
3,4-Anhydro-D-Galactosan & 12.670 & 1.42 & Carbohydrate derivatives \\
2,6-dimethoxy-phenol & 14.473 & 7.65 & Syringol and derivatives \\
4-Hydroxybenzaldehyde & 14.588 & 1.69 & Aldehydes \\
Vanillin & 15.175 & 2.50 & Guaiacol and derivatives \\
3,5-Dimethoxy-4-hydroxytoluene & 15.751 & 5.36 & Syringol and derivatives \\
Levoglucosan & 16.484 & 52.90 & Carbohydrate derivatives \\
1,2,3-trimethoxy-5-methylbenzene & 16.743 & 1.67 & Aromatic compounds \\
1-(4-hydroxy-3-methoxyphenyl) - 2- & 16.825 & 1.68 & Syringol and derivatives \\
propanone & 17.000 & 2.44 & Carbohydrate derivatives \\
4-o- $\beta$-d-galactopyranosyl-d-Glycopyranose & 17.595 & 1.22 & Carbohydrate derivatives \\
4-o- $\beta$-d-galactopyranosyl-d-Glycopyranose & 17.676 & 1.70 & Syringol and derivatives \\
2,6-dimethoxy-4-(2-propenyl) - phenol & 18.371 & 3.75 & Syringol and derivatives \\
4-hydroxy-3,5-dimethoxy-benzaldehyde & & & Syringol and derivatives \\
1-(4-hydroxy-3,5-dimethoxyphenyl) - & 19.188 & 3.86 & \\
Ethanone & 19.555 & 4.47 & - \\
Not identified & & &
\end{tabular}

$\mathrm{rt}=$ retention time (minutes). * Partly based on Guillén and Manzanos (2002).

tr $=$ tempo de retenção (minutos). * Baseado parcialmente em Guillén e Manzanos (2002).

\section{Physical properties of the aqueous phase and wood veneers}

Table 2 shows the physical properties of the WS and of the wood veneers. 
Table 2. Physical parameters of the WS, untreated wood, $\mathrm{WS}_{50}$ and $\mathrm{WS}_{10}$ treated wood veneers.

Tabela 2. Parâmetros físicos da WS e das lâminas de madeira não tratadas e tratadas com $\mathrm{WS}_{50} \mathrm{eWS}_{100}$.

\begin{tabular}{cccc}
\hline & Aqueous phase (WS) & \\
\hline Parameter & & $\mathrm{WS}_{50}$ & $\mathrm{WS}_{100}$ \\
Yield (Rws) $(\%)$ & - & $59.4(2.21)$ & $63.7(1.48)$ \\
$\mathrm{pH}$ & - & 3.28 & 3.44 \\
Solids content $(\%)$ & - & $12.15(0.89)$ & $12.49(1.03)$ \\
\hline & Wood veneers & & \\
\hline Parameter & Untreated & $\mathrm{WS}_{50}$ & $\mathrm{WS}_{100}$ \\
Density (g / L) & - & 0.999084 & 0.999004 \\
(WPG) (\%) - after impregnation & - & $8.97(1.97)$ & $10.14(3.22)$ \\
(WPG) (\%) - after drying & - & $3.11(0.8)$ & $3.54(1.33)$ \\
\hline
\end{tabular}

$\mathrm{R}_{\mathrm{WS}}=$ aqueous phase yield; $\mathrm{WPG}=$ weight gain percentage; values in parentheses correspond to the standard deviation

$\mathrm{R}_{\mathrm{WS}}$, rendimento da fase aquosa; WPG, ganho percentual de massa; Valores entre parênteses correspondem ao desvio-padrão.

\section{Surface morphology}

Figure 1 shows the morphology of the surface of Pinus elliotti wood veneers before and after $\mathrm{WS}_{50}$ and $\mathrm{WS}_{100}$ impregnation.

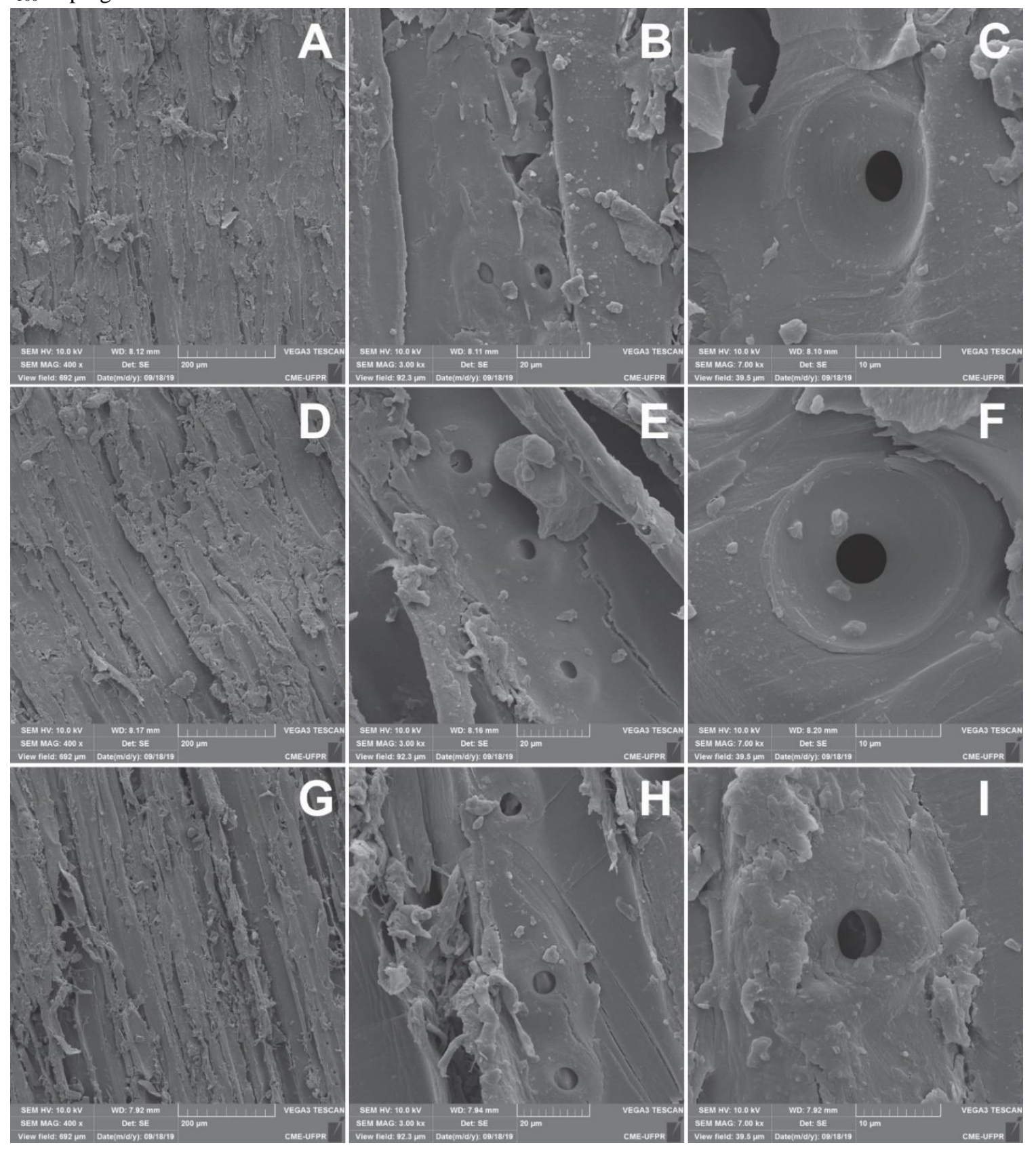

FLORESTA, Curitiba, PR, v. 51, n. 3, p. 557-566, jul/set 2021.

Sanson, C. S. L. et.al.

ISSN eletrônico 1982-4688

DOI: $10.5380 /$ rf.v51 i3. 70912 
Figure 1. High-resolution images of the morphology of untreated wood (A-C) and of wood treated with WS 50 (DF) and $\mathrm{WS}_{100}(\mathrm{G}-\mathrm{I})$.

Figura 1. Imagens de alta resolução da morfologia da madeira não tratada $(\mathrm{A}-\mathrm{C})$ e tratada com fase aquosa $\mathrm{WS}_{50}$ $(\mathrm{D}-\mathrm{F})$ e fase aquosa $\mathrm{WS}_{100}(\mathrm{G}-\mathrm{I})$.

\section{Thermal stability of untreated wood and wood treated with the aqueous phase}

The thermogravimetric analysis (Figure 2) shows in detail the thermal degradation behavior of the powder aqueous phase and the wood veneers of Pinus elliotti before and after impregnation with $\mathrm{WS}_{50}$ and $\mathrm{WS}_{100}$.
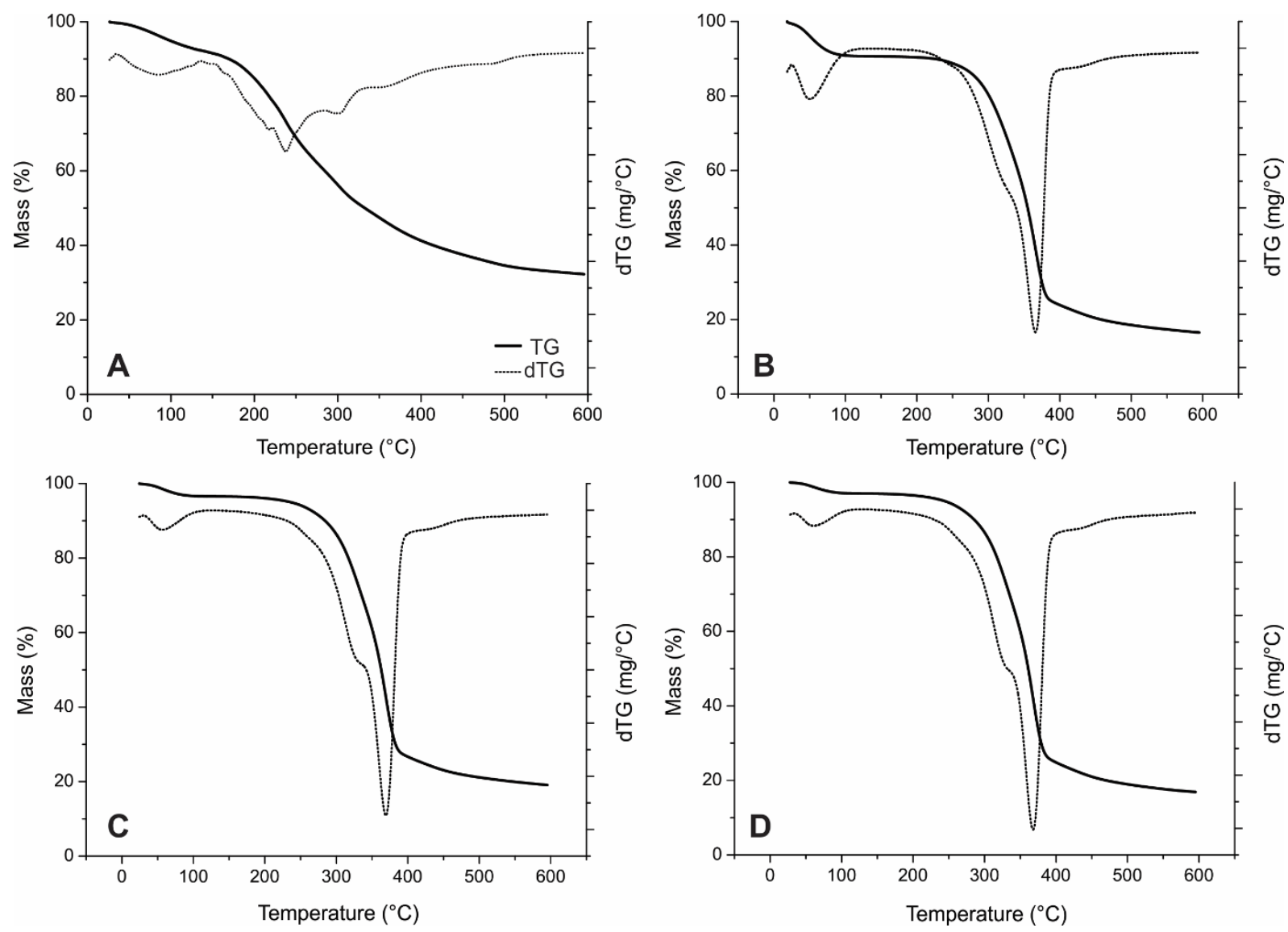

Figure 2. Thermogravimetric curves (TG) and their respective derivatives (dTG) for the aqueous powder phase (A), untreated Pinus elliotti wood (B), wood treated with $\mathrm{WS}_{50}(\mathrm{C})$ and wood treated with $\mathrm{WS}_{100}(\mathrm{D})$.

Figura 2. Curvas termogravimétricas (TG) e suas respectivas derivadas (dTG) para a fase aquosa em pó (A), madeira de Pinus elliotti não tratada (B), tratada com $\mathrm{WS}_{50}(\mathrm{C})$ e tratada com $\mathrm{WS}_{100}$ (D).

\section{Surface wettability}

The wettability of Pinus elliotti surface was significantly influenced by the presence of the WS after impregnation, for both 1:50 and 1:100 ratios (Table 3).

Table 3. Wettability parameters of untreated wood and with $\mathrm{WS}_{50}$ and $\mathrm{WS}_{100}$-treated veneers.

Tabela 3. Parâmetros de molhabilidade das lâminas de madeira não tratadas e tratadas com $\mathrm{WS}_{50} \mathrm{eWS}_{100}$.

\begin{tabular}{ccccc}
\hline \multirow{2}{*}{ Treatment } & \multicolumn{2}{c}{ Contact angle (WA) $\left(^{\circ}\right)$} & \multicolumn{2}{c}{ BD (mm) } \\
\cline { 2 - 5 } & WCA $(5 \mathbf{s})$ & WCA $(\mathbf{6 0 s})$ & BD $(\mathbf{5 s})$ & BD (60s) \\
\hline Untreated & $46.07(16.50)^{\mathrm{a}}$ & 0 & $20.12(5.60)^{\mathrm{a}}$ & 0 \\
$\mathrm{WS}_{50}$ & $125.74(9.10)^{\mathrm{b}}$ & $104.76(21.10)^{\mathrm{a}}$ & $42.10(12.40)^{\mathrm{b}}$ & $61.1(11.20)^{\mathrm{a}}$ \\
$\mathrm{WS}_{100}$ & $126.70(10.90)^{\mathrm{b}}$ & $102.97(19.40)^{\mathrm{a}}$ & $38.90(4.70)^{\mathrm{b}}$ & $45.36(8.80)^{\mathrm{b}}$ \\
F value & $260.73 *$ & $0.09^{\mathrm{ns}}$ & $28.24 *$ & $13.58 *$ \\
\hline
\end{tabular}

$\mathrm{BD}=$ diameter of the base of the water droplet. Values in parentheses correspond to the standard deviation. The values followed by the same letter in the column (between treatments) do not differ statistically from each other at the $95 \%$ confidence level by the Tukey mean test. $\mathrm{BD}=$ diâmetro da base da gotícula de água. Valores entre parênteses correspondem ao desvio-padrão. Os valores seguidos por uma mesma letra na coluna (entre tratamentos) não diferem estatisticamente entre si ao nível de confiança de $95 \%$ pelo teste de médias de Tukey. 


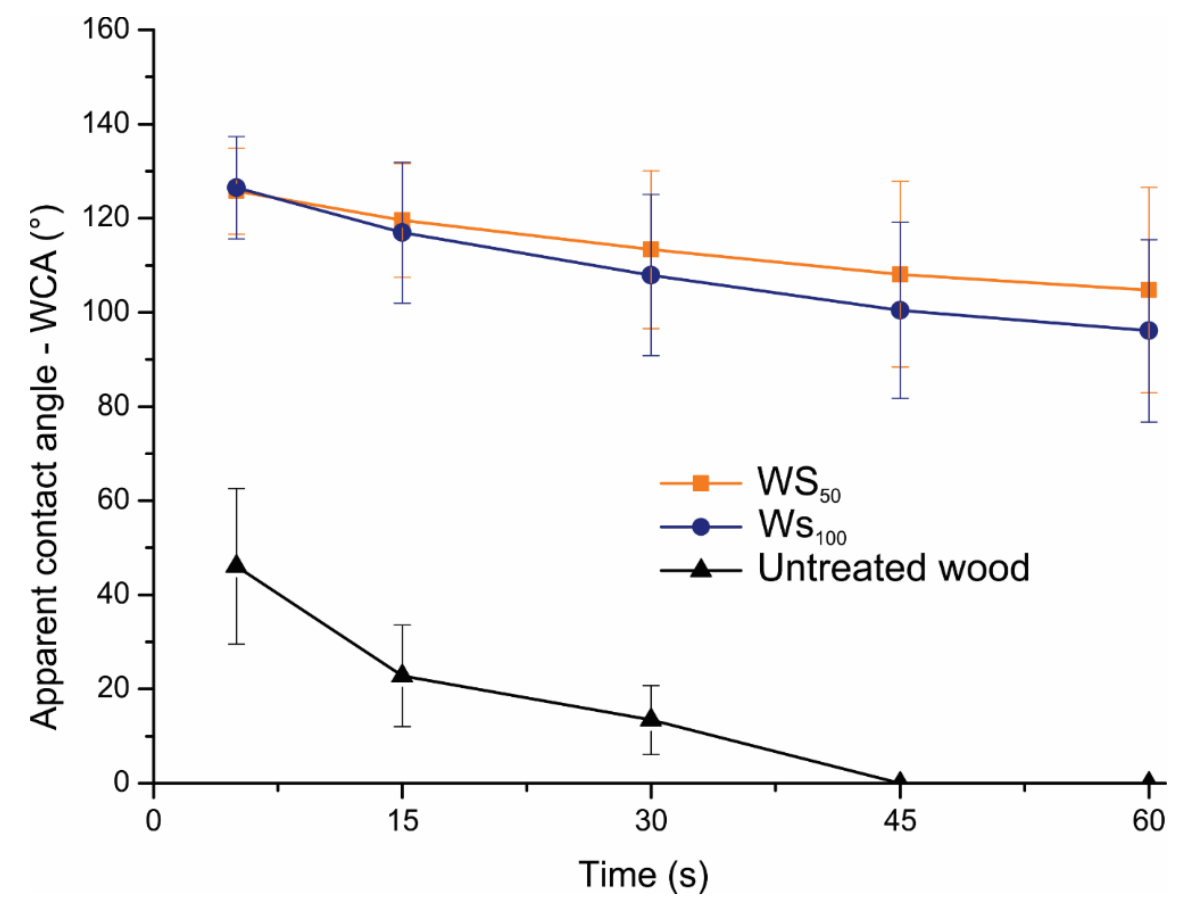

Figure 3. Kinetics of the contact angle of untreated wood and wood treated with $\mathrm{WS}_{50}$ and $\mathrm{WS}_{100}$ on the first day of evaluation after impregnation.

Figura 3. Cinética do ângulo de contato da madeira não tratada e tratada com $\mathrm{WS}_{50} \mathrm{e} \mathrm{WS}_{100}$ no primeiro dia de avaliação após impregnação.

\section{Stability of the degree of repellency of wood treated with the aqueous phase}

Figure 4 shows that the aging period for 45 days did not substantially affect the water repellency of the wood surface treated with $\mathrm{WS}_{100}$ when compared to the values obtained for $\mathrm{WS}_{50}$.
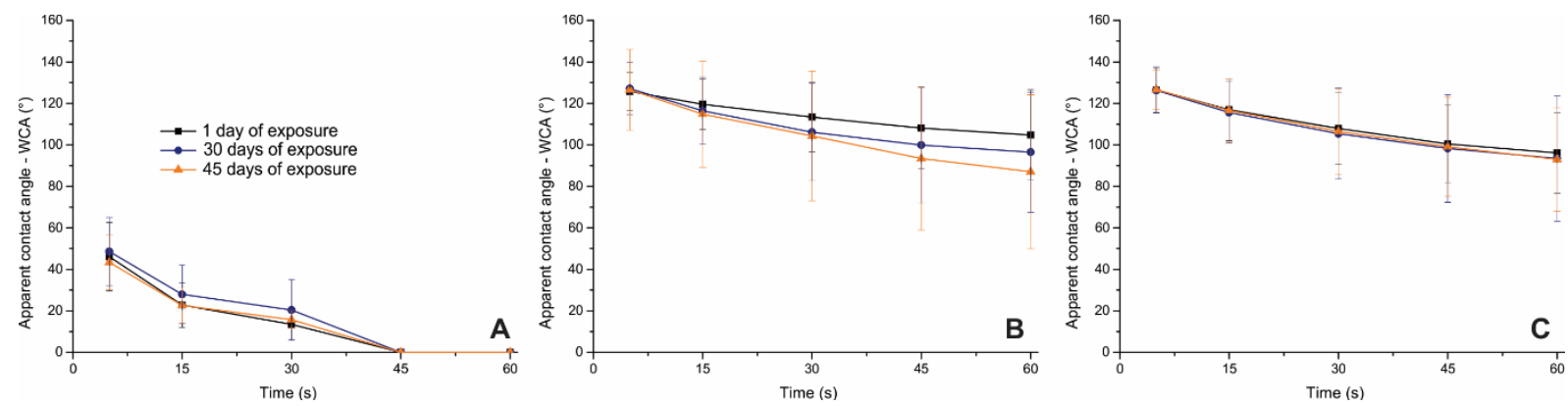

Figure 4. Kinetics of the contact angle of untreated wood (A) and wood treated with $\mathrm{WS}_{50}(\mathrm{~B})$ and $\mathrm{WS}_{100}(\mathrm{C})$ after 45 days of natural aging in a controlled environment.

Figura 4. Cinética do ângulo de contato da madeira não tratada (A) e tratada com $\mathrm{WS}_{50}(\mathrm{~B})$ e $\mathrm{WS}_{100}(\mathrm{C})$ após 45 dias de envelhecimento natural em ambiente controlado.

\section{DISCUSSION}

\section{Chemical composition by GC-MS}

The analysis of GC-MS (Table 1) showed that the chemical compounds identified may have an influence on the surface protection of lignocellulosic materials such as wood, especially compounds resulting from the degradation of lignin, which is recognized as a component that confers greater hydrophobicity when compared to cellulose (AKIN, 2010). These chemical compounds derive mainly from the degradation of cellulose, hemicellulose, and lignin present in wood. The main compound (>50\%) is levoglucosan (rt 16.484), part of the anhydrous sugars group, which originates from cellulose thermal degradation (LEE et al., 2010). During fast pyrolysis, the breakdown of glycosidic bonds $(\beta 1 \rightarrow 4)$ substantially contributes to the formation of levoglucosan and furans (WU et al. 2016), as observed in this study for the WS. We also identified catechol (rt 12.112) and vanillin (rt 15.175), both part of the hydroxybenzene group, in smaller proportions. In addition to these, we also identified other compounds that can influence the action of the aqueous phase as a water-repellent agent for wood, 
mainly phenolic compounds from lignin degradation. These compounds present in the lignin structure and observed in the WS are known for increasing the water-resistance of some materials, as observed by Yang and Pan (2016) in films containing lignin.

\section{Physical properties of the aqueous phase and the wood veneers}

There is a discrepancy between the WS yield shown in Table 2 and the yield from previous studies that focused on obtaining pyrolytic lignin. Zhang and $\mathrm{Wu}$ (2019), for example, obtained $36.56 \%$ of WS under fractionation conditions with a temperature of $20^{\circ} \mathrm{C}$ and a $1: 20$ ratio (water:bio-oil).

A higher water content during fractionation has a positive influence on WS yield. Consequently, a lower bio-oil:water (1:50) ratio makes it so that yield is directed towards the insoluble fraction (pyrolytic lignin).

The $\mathrm{pH}$ of the aqueous phase resembles that of crude bio-oil, ranging from 3.1 to 3.6 (Table 2), as described in the literature (LUQUE et al, 2016). However, the solution becomes slightly less acidic when water (5 to $7 \mathrm{pH}$ ) is added, due to the extraction of the phenolic compounds of hydrophobic nature that confer acidity to bio-oil.

The two proportions of bio-oil:water used showed no change in solids content. The density of the WS is similar to that of water at the same temperature $\left(20^{\circ} \mathrm{C}\right)$ and is slightly lower due to the dissolution of bio-oil compounds.

The impregnation of the wood veneers with the WS in both proportions resulted in a WPG between 3 and 4\%; these values were obtained after the wood was dried. This suggests that the solid material remained in the wood structure as the WS naturally dissolved in a liquid medium with a concentration of less than $1 \%$.

\section{Surface morphology}

Figure 1 shows that there were no substantial changes in the morphological appearance of the wood surface due to surface coating with WS impregnation, regardless of whether the proportion was 1:50 or 1:100. Qualitatively, the surface roughness remained unchanged (Figure 1 A, D, and G) and there was no surface coating of the WS treated Pinus elliotti wood (Figure 1 C, F, and I) when compared to the untreated material.

The lack of coating of the pits and the whole surface may be related to the low concentration of aqueous fractions used in this study, which prevents the formation of a homogeneous film on the wood surface. The fractionation, regardless of the proportions used, resulted in a liquid with a near or below $1 \%$ concentration. The results differ from Lourençon et al. (2016), in which the authors used crude bio-oil in concentrations of $10 \%, 50 \%$, and $100 \%$, and they observed total surface coating of tracheids in Pinus taeda wood.

\section{Thermal stability of untreated wood and wood treated with the aqueous phase}

The thermogravimetric analysis shows that there were no substantial changes in the thermal stability of the materials impregnated with $\mathrm{WS}_{50}$ and $\mathrm{WS}_{100}$ (Figure 2). The thermogram of the powdered aqueous phase (Figure 2A) shows a more intense loss of mass within the range of 150 to $300{ }^{\circ} \mathrm{C}$. This may be related to the chemical composition identified in Table 1, which shows the presence of anhydrous sugars in the aqueous phase and other chemical compounds with degradation temperature in this range.

The temperature and duration of the applied treatment are the main determinants of how the degradation of wood compounds occurs (ESTEVES; PEREIRA, 2009). The hygroscopic water evaporated from the wood as it reached $100{ }^{\circ} \mathrm{C}$. The untreated wood showed a greater loss of mass in this range, which can be associated with greater retention of liquids, unlike the wood treated with WS. This suggests an influence of the presence of chemical compounds from the WS, the impregnating agent used to treat wood veneers.

Hemicellulose degradation occurs within the temperature range of 225-325 ${ }^{\circ} \mathrm{C}$ (ROWELL, 2005), and all treatments had similar behavior. In this temperature range, there was a higher loss of sample mass ( $27 \%$ untreated wood, $30 \% \mathrm{WS}_{100}$ and $32 \% \mathrm{WS}_{50}$ ) and a shift in the peaks of the derivative, which represent the hemicelluloses. Similarly, treatments with $\mathrm{WS}_{50}$ and $\mathrm{WS}_{100}\left(320-345^{\circ} \mathrm{C}\right)$ had the same effect when compared to untreated material $\left(300-320^{\circ} \mathrm{C}\right)$, which indicates a possible influence of levoglucosan and/or other polar fragments from hemicelluloses on the composition of the aqueous phase, as shown in Table 1 for GC-MS. This behavior of loss of mass curve can be associated with the presence of levoglucosan because this chemical compound starts its degradation at $400{ }^{\circ} \mathrm{C}$ (FUKUTOME et al. 2017). Levoglucosan is a compound found in bio-oil that is produced during the process of fast pyrolysis of biomass through cellulose degradation (CHANG et al. 2011). The presence of this compound may have delayed the degradation of the wood treated with the WS.

The residual mass of the untreated and WS-impregnated wood veneers remained between 16 and 19\%, which highlights the absence of substantial changes in thermal stability since these values were similar for untreated wood and for impregnated wood. 


\section{Surface wettability}

Unlike what was observed for surface morphology and thermal stability, even with a low concentration, the WS significantly increased the hydrophobicity of the wood surface (Table 2). The kinetic behavior is evident in Figure 4, with the dynamics of the WCA on the first day.

The mean WCA after $5 \mathrm{~s}$ of deposition on the wood surface increased in around $63 \%$ with the $\mathrm{WS}_{50}$ treatment and $64 \%$ with the $\mathrm{WS}_{100}$ treatment, reaching values around $126^{\circ}$. The untreated wood had high hydrophilicity, reaching total wettability of the surface $\left(\mathrm{WA}=0^{\circ}\right.$ ) after $30 \mathrm{~s}$ of deposition of the water droplet, while the $\mathrm{WS}_{50}$ and $\mathrm{WS}_{100}$ treatments remained with a WCA around $100^{\circ}$ after $60 \mathrm{~s}$ of contact with water. Thus, the treatment with the aqueous phase transformed the highly hydrophilic surface of the wood of Pinus elliotti into a surface with a substantial degree of repellency to polar liquids. Considering the low concentration of the WS impregnated to Pinus elliotti wood $(<1 \%)$, the results found in this study show the efficiency of the treatment to create a water-repellent surface when compared to previous studies with other wood modification methods, such as thermal modification (thermomechanical densification (BEKHTA; KRYSTOFIAK, 2016), and fast pyrolysis bio-oil impregnation with high solids concentration (100\%) (LOURENÇON et al. 2016).

The chemical composition of the WS significantly influenced the increase in the degree of surface repellency. The presence of compounds of phenolic nature, such as furan, furfural, and benzaldehyde that originate from lignin, previously described in Table 1, contributed to the increase of the superficial hydrophobicity of the wood after impregnation with the WS. Products based on or containing lignin derivatives with this hydrophobic characteristic have already been studied (YANG; PAN, 2016).

As evidenced by the behavior of the base droplet diameter (BD) parameter (Table 2), the untreated wood presented a $5 \mathrm{~s}$ average $\mathrm{BD}$, twice lower than the average $\mathrm{BD}$ of wood treated with $\mathrm{WS}_{50}$ and $\mathrm{WS}_{100}$, reaching zero value after 30s of deposition on the surface, that is, the total absorption of the water droplet by the wood surface. On the other hand, the $\mathrm{WS}_{50}$ and $\mathrm{WS}_{100}$-treated woods showed an increase in DB, especially in the $\mathrm{WS}_{50}$ treatment, which indicates a lower incidence of the absorption phenomenon and greater capacity to spread the droplet over the surface. This suggests the formation of a thin protective layer on the wood surface after impregnation with the WS.

\section{Stability of the repellency degree of wood treated with the aqueous phase}

The untreated wood maintained high hydrophilicity; the water droplet was totally absorbed by the surface up to $30 \mathrm{~s}$ after deposition (Figure 4).

The $\mathrm{WS}_{50}$ and $\mathrm{WS}_{100}$ treatments have not resulted in substantial changes. For example, even after 45 days of natural aging in a climatic chamber, the variation in the WCA of both treatments was at most $1 \%$, reaching $10 \%$ and $17 \%$ variation after $60 \mathrm{~s}$ for $\mathrm{WS}_{50}$ and $\mathrm{WS}_{100}$, respectively. This indicates that the $\mathrm{WS}_{50}$ treatment was more stable than the $\mathrm{WS}_{100}$ treatment. Despite the partial reduction of the WCA after 45 days of aging, Pinus elliotti wood maintained its surface hydrophobicity.

\section{CONCLUSIONS}

- Pinus elliotti veneers impregnated with the aqueous phase of bio-oil showed characteristics of hydro repellency, without substantial changes in the morphology of its surface, that is, an absence of surface coating of the anatomical elements.

- Taking into account the absence of morphological surface changes (presence of a surface coating film), this water-repellent feature of the surface is likely related to the chemical composition of the aqueous phase, mainly formed by fragments originating from thermal degradation via fast pyrolysis of the main chemical components of wood (cellulose, hemicellulose, and lignin).

- It is evident that the aqueous phase of the fast pyrolysis bio-oil of eucalyptus can be used as a protective agent for the wood surface against the action of polar liquids without losing its efficiency after natural aging of the material.

\section{ACKNOWLEDGEMENTS}

The present study was carried out with the support of the Coordenação de Aperfeiçoamento de Pessoal de Nível Superior - Brazil (CAPES) - Financing Code 001, CNPq (grant number 422934/2018-6) and Fundação Araucária (grant number 048/2020). The authors would like to thank the technical support of Embrapa Florestas, Laboratório de Anatomia e Qualidade da Madeira (LANAQM-UFPR), Grupo de Cromatografia e Técnicas de Microextração (CroMe-UFPR) and Centro de Microscopia Eletrônica (CME-UFPR) in carrying out this study. The author(s) would also like to thank the Academic Publishing Advisory Center (Centro de Assessoria de Publicação Acadêmica, CAPA - www.capa.ufpr.br) of the Federal University of Paraná (UFPR) for assistance with English language translation and editing, and Suzano Papel e Celulose for the kindly donation of the bio-oil.

FLORESTA, Curitiba, PR, v. 51, n. 3, p. 557-566, jul/set 2021.

Sanson, C. S. L. et.al.

ISSN eletrônico 1982-4688

DOI: $10.5380 /$ rf.v51 i3. 70912 


\section{REFERENCES}

AKIN, D. E.; EDER, M.; BURGERT, I.; MÜSSIG, J.; SLOOTMAKER, T. What Are Natural Fibres? Industrial Applications of Natural Fibres, New Jersey (USA), Wiley Online Books, 2010.

BASUR, P. Production of Synthetic Fuels and Chemicals from Biomass. In: BASU, P. Biomass gasification and pyrolysis. Boston: Ed. Academic Press, 2010. 376 p., 301-323.

BEKHTA, P.; KRYSTOFIAK, T. The influence of short-term thermo-mechanical densification on the surface wettability of wood veneers. Maderas. Ciencia y tecnología, Concepción (Chile), v. 18, n. 1, p. 79 - 90. 2016.

BRIDGWATER, A.V.; Renewable Fuels and Chemicals by Thermal Processing of Biomass. Chemical Engineering Journal, Amsterdam (Netherlands), v. 91, p. 87 - 1020, 2003.

CAMPOS, Â. D. Técnicas para Produção de Extrato Pirolenhoso para Uso Agricola. Circular Técnica - Embrapa Clima Temperado, Pelotas, v. 65, 2007.

CANAl, W. D.; CARVAlho, A. M. M. L.; OliVEIRA, A. C. MAGAlHÃES, M. A.; CÂNDIDO, W. L.; FIALHO, L. F. Comportamento térmico, emissão de gases condensáveis e não condensáveis no processo de carbonização da madeira. Pesquisa Florestal Brasileira, Colombo, v. 36, n. 87, p. 261-267, 2016.

CHANG, S.; ZHAO, Z.; ZHENG, A.; LI, X.; WANG, X. Effect of hydrothermal pretreatment on properties of bio-oil produced from fast pyrolysis of eucalyptus wood in a fluidized bed reactor. Bioresource Technology, Amsterdam (Netherlands), v. 138, p. $321-328,2013$.

ESTEVES, B.; PEREIRA, H. Wood modification by heat treatment: A review. BioResources, Raleigh (USA), v. 4, n. 1, p. 370-407, 2009.

FUKUTOME, A.; KAWAMOTO, H.; SAKA, S. Gas-phase pyrolysis of methyl glucosides and levoglucosan. Journal of Wood Science, Tokyo (Japan), v. 63, n. 3, p. 295-306, 2017.

GARCIA-PEREZ, M.; CHAALA, A.; PAKDEL, H.; KRETSCHMER, D.; ROY, C. Characterization of bio-oils in chemical families. Biomass and Bioenergy, Amsterdam (Netherlands), v. 31, n. 4, p. 222-242, 2007.

GUILLÉN, M. D.; MANZANOS, M. J. Study of the volatile composition of an aqueous oak smoke preparation. Food Chemistry, Amsterdam (Netherlands), v. 79, n. 3, p. 283-292, 2002.

JIANG, X.; ELLIS, N.; ZHONG, Z. Characterization of Pyrolytic Lignin Extracted from Bio-oil. Chinese Journal of Chemical Engineering, Beijing (China), v. 18, n. 6, p. 1018-1022, 2010.

LEE, T.; SUlLIVAN, A. P.; MACK, L.; GIMENEZ, J. L.; KREIDENWEIS, S. M.; ONASCH, T. B.; WORSNOP, D. R.; MALM, W.; WOLD, C. E.; HAO, W. M.; COLLETT jr, J. L. Chemical Smoke Marker Emissions During Flaming and Smoldering Phases of Laboratory Open Burning of Wildland Fuels. Aerosol Science and Technology, Reston (USA), v. 44, n. 9, p. i-v, 2010.

LUQUE, R.; CAMPELO, J.; CLARK, J.H. Handbook of biofuels production: processes and Technologies. Philadelphia: Woodhead Publishing, 2011. 770 p.

MIRASOL F, Acetic acid. ICIS Chemical Business, London, 275 (2009)

MOHAN, D.; PITTMAN, C. U.; STEELE, P. H. Pyrolysis of Wood/Biomass for Bio-oil: A Critical Review. Energy \& Fuels, Washington (USA), v. 20, n. 3, p. 848-889, 2006.

QIN, W.; KADLA, J. F. Carbon fibers based on pyrolytic lignin. Journal of Applied Polymer Science, New Jersey (USA), v. 126, n. S1, p. E204-E213, 2012.

RASRENDRA, C. B.; GIRISUTA, B.; VAN DE BOVENKAMP, H. H.; WINKELMAN, J. G. M.; LEIJENHORST, E. J.; Recovery of acetic acid from an aqueous pyrolysis oil phase by reactive extraction using tri-n-octylamine. Chemical Engineering Journal, Amsterdam (Netherlands), v. 176-177, p. 244-252, 2011.

ROWELL, R. M. Handbook of wood chemistry and wood composites. New York: CRC Press, 1 $1^{\mathrm{a}}$. Edition, 2005. 487 p.

VITASARI, C. R.; MEINDERSMA, G. W.; DE HAAN, A. B. Water extraction of pyrolysis oil: The first step for the recovery of renewable chemicals. Bioresource Technology, Amsterdam (Netherlands), v. 102, n. 14, p. 7204-7210, 2011.

YANG, Q.; PAN, X. Correlation between lignin physicochemical properties and inhibition to enzymatic hydrolysis of cellulose. Biotechnology and Bioengineering, New Jersey (USA), v. 113, n. 10, p. 1213-1224, 2016.

WU, S.; SHEN, D.; HU, J.; ZHANG, H.; XIAO, R. Role of $\beta-O-4$ glycosidic bond on thermal degradation of cellulose. Journal of Analytical and Applied Pyrolysis, Amsterdam (Netherlands), v. 119, p. 147-156, 2016.

ZHANG, X.; MA, H.; WU, S.; JIANG, W.; WEI, W.; LEI, M. Fractionation of pyrolysis oil derived from lignin through a simple water extraction method. Fuel, Amsterdam (Netherlands), v. 242, p. 587-595, 2019.

ZHANG, M.; WU, H. Pyrolytic lignin from fast pyrolysis bio-oil via cold-water precipitation: Optimal separation conditions and properties. Fuel, Amsterdam (Netherlands), v. 242, p. 580-586, 2019.

ZHAO, Y.; DENG, L.; LIAO, B.; FU, Y.; GUO, Q.-X. Aromatics Production via Catalytic Pyrolysis of Pyrolytic Lignins from Bio-Oil. Energy \& Fuels, Washington (USA), v. 24, n. 10, p. 5735-5740, 2010. 